\title{
RELATIONSHIP BETWEEN FAITH AND SCIENCE IN THE MAJOR WORLD RELIGIONS
}

\author{
Ph.D. Alexandru-Corneliu ARION \\ Faculty of Theology and Sciences of Education, \\ "Valahia" University of Târgovişte, \\ ROMANIA, \\ E-mail: alexcoarion@yahoo.co.uk
}

\begin{abstract}
Even though on Religion and Science opposition an impressive amount of blood has been shed, today many scientists, philosophers, and theologians throughout history have seen compatibility or independence between the two domains of thinking. The complex but enduring relationship between the sciences and diverse world religions has now transformed itself into what some are calling a new scholarly field of science and religion. In the last two decades public awareness of and interest in this complex and often contentious relationship between science and religion has reached an unprecedented level. All religious traditions and all forms of scientific work have something to gain as well as lose in the process of mutual interaction, and the historical record demonstrates profound and longstanding engagement between science and religion in all literate cultures.
\end{abstract}

Keywords: science; religions; faith; conflict; interaction; harmony; Christianity; Orthodoxy; Islam; Hinduism; Buddhism;

\section{INTRODUCTION}

One of the most disputed chapters in the last millennium human debate is that of the relation between religion and science, or between the model of faith and that of human reason concerning the true knowledge of man and universe. In fact, this very relationship between the two domains of knowledge has been a subject of study since classical antiquity, addressed by philosophers, theologians, scientists, and others. Perspectives from different cultures and historical epochs are so diverse, with some characterizing the relationship as one of conflict, others describing it as one of harmony, while others proposing little interaction.

Both science and religion constitute complex social and cultural endeavours that vary across cultures and have changed over time. ${ }^{1}$ And there is an undisputable fact that most scientific and technical innovations prior to the scientific revolution were achieved by societies organized by religious traditions. Elements of the scientific method were pioneered by ancient pagan, Islamic, and Christian scholars. Therefore, at a very first glance one can notice some very relevant samples. Thus, during the so-called Islamic Golden Age foundations for the scientific method were laid by Ibn al-Haytham. ${ }^{2}$ In Christianity, the

\footnotetext{
${ }^{1}$ Mikael Stenmark, How to Relate Science and Religion: A Multidimensional Model, Grand Rapids, Mich.: W.B. Eerdmans, 2004, p. 45.

${ }^{2}$ It is this very tradition that provides the historical context for the work of Ibn al-Haytham (Latin Alhacen, cca. 1040) on the foundations of Euclidean geometry, leading him in the process to prove theorems in nonEuclidean geometry, including a formulation of what is today called the Strong Hilbert Axiom of Parallels. And it is this very environment of large-scale feverish mathematical research that explains the appearance of
} 
renowned scholastic Roger Bacon, who is often credited with formalizing the scientific method, was a Franciscan friar. ${ }^{3}$

On the same time, the Eastern Religions played also a crucial role for that matter. Hinduism has historically embraced reason and empiricism, holding that science brings legitimate, but incomplete knowledge of the world. Confucian thought has held different views of science over time. Most Buddhists today view science as complementary to their beliefs. While the classification of the material world by the ancient Indians and Greeks into air, earth, fire and water was more philosophical, medieval Middle Eastern used practical and experimental observation to classify materials. ${ }^{4}$

Thereafter, events in Europe such as the Galileo affair, associated with the scientific revolution and the Age of Enlightenment, led scholars such as John William Draper (19th century) to postulate the famous and oft-disputed conflict thesis, holding that religion and science have been in conflict methodologically, factually and politically throughout history. This thesis is held by some contemporary scientists such as Richard Dawkins, Steven Weinberg and Carl Sagan, and some creationists. The conflict thesis has lost favour among most contemporary historians of science. ${ }^{5}$ As the American historian and sociologist of science Steven Shapin has put it:

\begin{abstract}
"in the late Victorian period it was common to write about the 'warfare between science and religion' and to presume that the two bodies of culture must always have been in conflict. However, it is a very long time since these attitudes have been held by historians of science." 6
\end{abstract}

Many scientists, philosophers, and theologians throughout history, such as Francisco Ayala, Kenneth R. Miller and Francis Collins, have seen compatibility or independence between religion and science. Biologist Stephen Jay Gould, other scientists, and some contemporary theologians hold that religion and science are non-overlapping magisteria, addressing fundamentally separate forms of knowledge and aspects of life. Some theologians or historians of science, including John Lennox, Thomas Berry and Ken Wilber propose an interconnection between science and religion, while others such as Ian Barbour believe there are even parallels.

But, rigorously, both concepts of "science" and "religion" are a recent invention: the latter emerged in the 17th century in the midst of colonization and globalization and the Protestant Reformation, ${ }^{7}$ while the former emerged in the 19th century in the midst of attempts to narrowly define those who studied nature, ${ }^{8}$ and the phrase "religion and science" loomed large in the 19 th century due to the reification of both concepts. It was in the 19th

decimal fractions in Arabic writings some six centuries before one finds them in the Latin West. Syed Nomanul HAQ, "Science in Islam", in: Oxford Dictionary of the Middle Ages, Oxford University Press, 2010. See also: Islam \& Science, Vol. 7 (Winter 2009), No. 2, p. 153.

${ }^{3}$ Brian ClegG, The First Scientist: A Life of Roger Bacon, Carroll and Graf Publishers, New York, 2003.

4 Science and Islam, Jim Al-KHALILI, BBC, 2009, apud Relationship between religion and science. See: https://en.wikipedia.org/wiki/Relationship_between_religion_and_science\#cite_note-First_Scientist,_Clegg-4

${ }_{5}$ The conflict thesis, at least in its simple form, is now widely perceived as a wholly inadequate intellectual framework within which to construct a sensible and realistic historiography of Western science. Cf. C.A. RUSSEL Ferngren, G.B., ed., Science \& Religion: A Historical Introduction, Johns Hopkins University Press, 2002, p. 7.

${ }^{6}$ Steven SHAPIN, The Scientific Revolution, University of Chicago Press, 1996 p. 195.

${ }^{7}$ Peter HARRISON, The Territories of Science and Religion, University of Chicago Press, 2015, p. 79.

${ }^{8}$ David CAHAN, ed., From Natural Philosophy to the Sciences: Writing the History of Nineteenth-Century Science, Chicago: University of Chicago Press, 2003. 
century that the terms "Buddhism", "Hinduism", "Taoism", and "Confucianism" came to birth. ${ }^{9}$ In the ancient and medieval world, the etymological Latin roots of both science (scientia) and religion (religio) were understood as inner qualities of the individual or virtues, never as doctrines, practices, or actual sources of knowledge. ${ }^{10}$

\section{RELIGION AND SCIENCE IN CHRISTIANITY, DICHOTOMY OR ALLIANCE?}

Western culture was born from the encounter of Greek philosophy with the JudeoChristian religion. This encounter has also shaped our present sense that rational Christianity was not directly interested in investigating the world. It assimilated Greek rationality mainly because it had to construct its own theology on Greek concepts and language.

This assimilation was far from being only passive. The Christian God became the guarantor of rationality but, on the other hand, the Greek idea of rationality has infiltrated the very concept of God. The God of the philosophers, understood as a "closure of the world," has become a God of religion and worship.

Cooperation and conflict are the very essence of the relation between Christianity and the sciences. Cooperation, since both Christianity and science has their roots in Greek rationality; conflict because the fundamental Christian claim that God has entered into human history goes beyond the scientific method. In the eyes of Christian theology the world's rationality is but God's Logos immanent in the world. ${ }^{\text {I }}$

Christian theology was born in the period of the Church Fathers not as a product of intellectual curiosity but out of the need to practice and preach the new religion. There were two choices: either to be happy with common sense tenets or to undertake a process of rational reflection, and this meant using the resources of Greek philosophy. The first possibility was resignation rather than a choice. Two great personalities played an important role in this process: Origen paved the way, and Augustine established the standards for future generations. $^{12}$

\subsection{History of science and religion in Christianity}

The very beginning of the famous dichotomy is identified with the Enlightenment (18th century) and the French Encyclopaedism, even if its germs are to be found in the anthropocentric vision of the Renaissance.

"This attitude, which maintained for a long time the representatives of the two paradigms of thinking on schizoid positions, has its peak in the nineteenth century, that witnessed the emergence of evolutionary theories or of Pierre-Simon Laplace' cosmology, and in the twentieth century, which brought with it the radicalized secularization of communist regimes (who used the theoretical framework of dialectical and historical materialism). The two "camps" have long been in irreconcilable-antagonistic positions, very few bridges spanning between them". ${ }^{13}$

\footnotetext{
${ }^{9}$ Jason Ananda JOSEPHSON, The Invention of Religion in Japan, University of Chicago Press, 2012, p. 45.

${ }^{10}$ Peter HARRISON, The Territories of Science and Religion, p. 103.

${ }^{11}$ George V. COYNE \& Michael HeLler, A Comprehensible Universe. The Interplay of Science and Theology, Springer-Verlag, New York, 2008, p. 33.

${ }^{12}$ It is interesting to follow the laborious adaptations of the Greek model of the world to the needs of Christian theology. The greatest challenge was the biblical doctrine of creation. Early Christian writers, while not abandoning the original biblical meaning, did not, on the other hand, resist the Greek instinct to seek the "mechanisms" of the world's origin, and they elaborated the doctrine of creation ex nihilo. It was also a reaction against Gnostic teaching that the "principle of evil" is inherent and resident in matter. Ibid, p. 34.

${ }_{13}$ Alexandru-Corneliu ARION, "The origin of the world from science and religion perspectives", in: Icon of Faith, International Journal of Interdisciplinary Scientific Reasearch, Year 3, No. 6, June, 2017, pp. 38-39.
} 
The more important than the historical considerations in the conflict between the two domains of knowledge are the philosophical obstacles, especially the epistemological ones, which religion and theology pose to the sceptics of science. The main problem is that religious ideas seem not to be experimentally tested. In other words, they apparently escape the rigors of public scrutiny, while science always obeys the ideas of open experimentation. If an empirical research shows that a scientific hypothesis is wrong, science puts it aside and looks for alternatives, subjecting them to the same rigorous verification process. But can we do the same thing with religious teachings? Theists, for example, continue to believe in God, no matter what they observe around them, including enormous suffering and evil. The followers of scientific scepticism say that religion does not have the solid probity of science. The God-hypothesis, for example, seems to be totally out of any falsification, so it cannot be accepted by the 'courthouse' of science. On the other hand, within the many debates among the representatives of the two paradigms of knowledge, there have been several important names of philosophers of science or physicists who have pleaded for the Christian origin of modern science. ${ }^{14}$

But, after all, throwing a diachronic eye on the matter, the fundamental question facing the Christian scholar in any discipline can be seen as a specific form of a general query that was posed within two centuries of Christ's death by the Carthaginian father Tertullian (c. 155-230): "What indeed has Athens to do with Jerusalem? What concord is there between the Academy and the Church?" As the phrasing implies, Tertullian's attitude towards Greek philosophy was generally negative, though he acknowledged a legitimate role for reason within the bounds of religion. Other patristic authors looked more favorably on pagan philosophy and literature, especially Origen (c. 185-254), who required his students to read nearly every work available to them at the time and found some truth in most of them. The moderate position of Augustine of Hippo (354-430), who considered reason a divine gift resting on the foundation of faith, was by far the most influential on later Christian thinking. ${ }^{15}$

For nearly twelve hundred years Christian scholars were not confronted with the full force of Aristotle's sophisticated naturalism. On the other hand, they did have Plato's Timaeus, a dialogue about creation in which a god imposes mathematical form on undifferentiated matter. Although the differences between Plato's story and Genesis are significant, there are enough similarities that Plato was readily seen as a pagan prophet of Christianity. Plato's rejection of purely natural and unintelligent causes in forming the world, coupled with his belief in the immortality of the soul and the superiority of mind over matter, made him highly attractive to Christian writers. The relative ease with which Platonic

\footnotetext{
${ }^{14}$ We mention, inter alia, the Romanian physicist Basarab Nicolescu and the French philosopher Alexandre Kojève. See: Alexandru-Corneliu ARION, „Intâlniri cu Realitatea”. Repere pentru dialogul contemporan dintre teologie şi cultură ("Encounters with Reality". Landmarks for contemporary dialogue between theology and culture), Preface by Prof. Dr. Lucian Turcescu, Cetatea de Scaun, Târgovişte, 2017, p. 439-440.

${ }^{15}$ Although he cautioned Christians not to devote too much energy to the study of nature, which cannot lead to salvation, Augustine recognized Greek scientists as reliable authorities on natural matters and cautioned Christians against making nonsensical claims about nature, based on some presumed meaning of scripture, for this would only cause people to laugh at the ignorance of Christians. For details: David C. LINDBERG, and Ronald L. NumBers, eds. God and Nature: Historical Essays on the Encounter between Christianity and Science, Berkeley: University of California Press, 1986.
} 
elements could be incorporated into a Christian world view - and vice versa, depending on who was doing the philosophizing - gave considerable support to the handmaiden model. ${ }^{16}$

The situation changed dramatically with the reintroduction into Northern and Western Europe of a large body of Greek scientific and medical works. This process began around 1000 C.E. and led within two centuries to the appearance of universities dominated by Aristotelian natural philosophy, strongly flavored by the ideas of Islamic scholars who had worked with translations of Greek texts for hundreds of years. ${ }^{17}$

In the later middle ages and continuing into the Renaissance, partly in reaction to the hold Aristotelianism had gained on the universities, Platonism enjoyed a revival. Many Renaissance thinkers followed Plato by emphasizing mathematics as the key to understanding nature, but differed fundamentally from Plato in their belief that the physical world perfectly embodies God's geometrical design; Plato had taught that physical objects are only imperfect "shadows" of the perfect forms. The difference was a consequence of the Christian doctrine of creation: An omnipotent God would carry out the plan of creation to perfection. ${ }^{18}$ By the right use of geometry, one might literally read the mind of God and discover the deepest secrets of creation. Inspired partly by his neo-Platonist beliefs and strongly encouraged by church authorities to publish his ideas, the quiet and conservative Copernicus advanced a radical new theory of the universe that placed the Earth in motion about a stationary sun. J. Kepler found this theory attractive for several reasons, including his belief that the three parts of the Copernican universe symbolized the Trinity - the central sun with its emanating light representing God the Father, the starry sphere God the Son, and the intermediate space God the Holy Spirit. ${ }^{19}$

In defense of the new astronomy, Kepler (a German Protestant) and Galileo (an Italian Catholic) both employed the Augustinian principle of accommodation to justify the figurative interpretation of biblical references to the motion of the sun. The Bible, they argued, speaks in a human way about ordinary matters in a way that can be understood by the common person, using ordinary speech to convey loftier theological truths. Thus, the literal sense of texts making reference to nature should not be mistaken for accurate scientific statements, but the wise interpreter could show how the book of scripture did not really contradict the book of nature. ${ }^{20}$

More than a century later, Christian thinkers were reluctant to cite scripture on scientific matters, no doubt because the age and origin of the Earth had become topics of

\footnotetext{
${ }^{16}$ Arthur PEACOCKE, Theology for a Scientific Age: Being and Becoming-Natural, Divine, and Human, rev. edition, Minneapolis, Minn.: Fortress Press, 1993, p. 96.

17 The influence of Ibn Rushd (known in the West as Averroës, 1126-1198), an extreme rationalist who elevated Aristotle over traditional Islamic teaching, was especially important in this connection. Christian scholars were now faced with a powerful, systematic body of natural knowledge, comprehensive in scope and secular in spirit, and they responded in various ways. Cf. John Polkinghorne, Belief in God in an Age of Science. New Haven, Conn., Yale University Press, 1998.

18 For Christian neo-Platonists like Nicolas Copernicus (1473-1543), Galileo Galilei (1564-1642), and Johannes Kepler (1571-1630), God was eternally thinking geometric thoughts. Ibid, p. 136.

${ }^{19}$ Edward B. DAVIS, "Christianity, History of Science and Religion”, in Encyclopedia of Science and Religion, J. Wentzel Vrede VAN HUYSSTEEN, editor-in-chief, Thomson Gale, Macmillan Reference, USA, 2003, p.125.

${ }^{20}$ Citing rules established by the Council of Trent in response to Protestant reformers, Catholic authorities found this unacceptable and ordered Galileo not to teach the new astronomy. Galileo, who often treated opponents arrogantly, ignored this warning and published a vigorous attack on traditional astronomy in which he thoughtlessly insulted his friend, Pope Urban VIII, and Galileo was sentenced to house arrest by the Inquisition in 1633. Cf. Roland Mushat FrYE, "The Two Books of God", in Is God a Creationist?, Roland Mushat Frye, ed., New York: Scribner, 1983, p. 268.
} 
serious scientific discussion. Many natural historians and theologians saw in the books of nature and scripture essentially the same story, going beyond the general assumption of harmony to endorse a strong agreement, arguing for close parallels between Genesis and geology and sometimes inventing elaborate hermeneutical schemes to achieve harmonization.

But with the acceptance of Darwinian evolution, however, this type of agreement fell out of favor, though some conservative Protestants still embrace it, and no single approach to theology and science has generated a wide enough following to function as its replacement. The first American Darwinian, Asa Gray (1810-1888), thought that his acceptance of evolution had no bearing on his belief in the miracles of Christ and the doctrines affirmed by the Nicene Creed, thus holding a compatibilist or complementarian view of theology and science. At the same time, Gray tried to rebuild natural theology along evolutionary lines - a combination that has never been common, although a number of orthodox and neo-orthodox thinkers in the following century held some type of complementarian position. ${ }^{21}$

From the 1870s to the 1920s, many Protestant scientists and theologians and some Roman Catholics believed that higher biblical criticism, as well as natural science, mandated the formulation of a new theology stressing divine immanence, God's everyday working in and through the processes of nature..$^{22}$

Both world wars had a devastating impact on such an optimistic view, leading the English logician Alfred North Whitehead (1861-1947) argued that the very possibility of modern science depended upon the unconsciously held belief, derived from medieval theology, that the created order must be intelligible, thus finding an inextricable link between theology and science. He also developed a highly sophisticated process metaphysics that has profoundly influenced some important modern theologians, philosophers, and scientists. Motivated partly by a desire to embrace evolution and even more by a desire to mitigate God's responsibility for suffering, process theologians believe that God has only limited power to influence natural and human events, rather than the omnipotence needed to create the world ex nihilo.

The world and God are seen as coeval entities evolving together, and many contemporary process thinkers follow Charles Hartshorne (1897-2000) in affirming panentheism ${ }^{23}$ rather than traditional theism. Ironically, perhaps the greatest challenge to process theology comes from the modern science it seeks to embrace, but from the evolution of the cosmos rather than the evolution of life.

\footnotetext{
${ }^{21}$ Robert BoYLE, A Free Enquiry into the Vulgarly Received Notion of Nature (1686), ed. Edward B. Davis and Michael Hunter, Cambridge, UK: Cambridge University Press, 1996.

${ }^{22}$ Some liberals took this further, including several modernists from the 1920s who denied miracles and special revelation and essentially identified God with the laws of nature, thus completely rejecting divine transcendence. Liberals saw morality as the essence of religion; asserting the fundamental goodness and perfectibility of humanity, many also believed that the science of eugenics would help them establish the kingdom of God on Earth. See: Ian BArbour, Religion in an Age of Science: The Gifford Lectures, 19891991, Vol. 1. San Francisco: Harper-Collins, 1990, p. 235.

23 "Panentheism" is a constructed word equivalent of the Greek terms "pan", meaning all, "en", meaning in, and "theism", meaning God. Pan-en-theism considers God and the world to be inter-related with the world being in God and God being in the world. It offers an increasingly popular alternative to both traditional theism and pantheism. Panentheism seeks to avoid either isolating God from the world as traditional theism often does or identifying God with the world as pantheism does. Traditional theistic systems emphasize the difference between God and the world while panentheism stresses God's active presence in the world and the world's influence upon God. See John CULP, "Panentheism”, The Stanford Encyclopedia of Philosophy (Summer 2017 Edition), Edward N. Zalta (ed.), URL = https://plato.stanford.edu/archives/sum2017/entries/panentheism/
} 
"Since the mid-1960s, astronomers have discovered a wealth of evidence favoring the Big Bang theory of cosmology; evidence suggesting not only that the universe had a 'beginning' but also that the laws of nature were exquisitely tuned for the presence of living things. Many think that a universe with these features seems more consistent with creatio ex nihilo than its denial". ${ }^{24}$

At the dawn of the twenty-first century, a good number of leading Christian scientists and theologians including some who combine that role such as Ian Barbour (1923-2013), Arthur Peacocke (1924-2006), and John Polkinghorne (1930- ), are engaged in a growing international conversation about issues of interest to both communities, and the range of opinion reflects disagreements about the nature of God, the nature of humanity, and the nature of nature. ${ }^{25}$

\subsection{Science and religion in Orthodoxy}

In the first centuries of Christianity, the attitude to the sciences was established in the context of its encounter with classical Hellenistic culture. Since Clement of Alexandria (c. 150-215), philosophy and the sciences were considered human activities cooperating in ultimate truth, as useful tools in order to defend faith and make it demonstrable, and important for Christian education. The Greek Fathers asserted that scientific knowledge is incomplete in itself and must be supported by wider views of reality, which are accessible through faith. Knowledge and the sciences thus have their foundation in faith. ${ }^{26}$

Today it is clear that the impetuous energies of the human-minded spirit begin to quench, so that we do not signal - only very sporadically - the "tantrums" of the scientists against the adepts of religious thinking. For at the epistemological level in the dispute of science versus religion, it is becoming increasingly clear that the scientific model, blocked for centuries in its reductionist prejudices, seems to be now intuitively bringing near the prospects of a deeper knowledge, of the spirit of the theological demarche.

The encounter between theology and culture is rather a way of life manifested by the assumption of certain methodological landmarks. Today, we are more than ever aware that theology can affirm a "culture of Spirit" (R. Noica) as space of the encounter between divine grace and human knowledge, between the word of God and the human word. The ReligionScience dialogue, where the two are equal partners of that dialogue, without mingling and without separation, calls for the effort of theological interpretation of culture, because what can give consistency to culture, as fruit of the mind and human sensibility, is not human reason alone, but the divine-human reason, whereon theology is built.

The information explosion from the beginning of the third millennium, the scientific discoveries located near the border with fiction, the globalization of such a heterogeneous world, the preservation of the identity of each nation raises as many questions as to a future that everybody desires full of love and peace. It seems that the only landmark that remains to most of us in a more and more troubled world is faith.

But as we turn to faith, we ask ourselves more often: how can we believe in the reconciliation between an incredibly advanced science and a faith that seems to turn us back to the past? That is presumably a question that has long stirred the Western world, but to which we, the Romanians hardly dare to think now, after the collapse of communism. The

\footnotetext{
${ }^{24}$ Edward B. DAVIS, "Christianity, History of Science and Religion”, p. 126.

${ }^{25}$ See also John H. Brooke, Science and Religion: Some Historical Perspectives. Cambridge, UK: Cambridge University Press, 1991; Edward B. DAVIS, "The Word and the Works: Concordism and American Evangelicals", in: Perspectives on an Evolving Creation, ed. Keith Miller. Grand Rapids, Mich.: Eerdmans, 2002.

${ }^{26}$ Fr. PhD. Alexandru-Corneliu ARION,"The origin of the world from science and religion perspectives", p. 40.
} 
elusion of the present data of the science-religion ratio results in the violent confrontation of traditional cultures and religions, threatened in this way with the evanescence or at least taking over the reins by a global culture and world religion, both based on the same denominator, i.e. on an absolute mediocrity. In this context, the dialogue between science and Orthodox theology can contribute to the reconfiguration of globalization itself, which can achieve less schizoid or spiritual traumatic accents. Orthodoxy, at least in its patristic foundations and in those of contemporary theologians as well as, has always been open to the understanding of nature by integrating it into the divine act. ${ }^{27}$

\section{RELIGION AND SCIENCE IN ISLAM}

The word Islam means "surrender or submission" to God's will. It also means "peace." In a sense, it is through submission to the divine will that a human attains inner peace. One who submits to the divine will is called Muslim. ${ }^{28}$

In the nineteenth century, the Muslim world's encounter with modern science took the form of a double challenge, simultaneously material and intellectual. The Ottoman Empire's defense against the military rise of Western countries, followed by successful colonization, made it necessary to acquire Western technology, and, therefore, the science behind it. The pressure of modern science on Islam has remained very strong. The West appears as the model of progress that the Muslim world has to reach, or at least follow, through the training of technicians and engineers and through the massive transfer of those technologies that are key to development. But more than anything else, the encounter of Islam with modern science stimulated philosophical and doctrinal thinking, provoked in some fashion by an inaugural event, the famous lecture titled "Islam and Science," which Ernest Renan (†1892) delivered at the Sorbonne (in 1883). In the lecture, where he expressed his own positivist perspective, Renan criticized the Muslims' utter inability to produce scientific discoveries, as well as their supposed inability to think rationally. ${ }^{29}$

Intellectual Muslims of the time, who were in contact with the Western intelligentsia, considered the lecture offensive. Those intellectuals then championed the idea that Islam never experienced a rupture between science and religion, whereas Christianity, and especially Catholicism, had known a long period of conflict with science. They argued that modern science is nothing other than "Muslim science" developed long ago in the classical era of the Umayyad and Abbasid caliphates, and finally transferred to the West in thirteenthcentury Spain, thanks to translations that later would make possible both the Renaissance and the Enlightenment. ${ }^{30}$

From an Islamic standpoint, science, the study of nature, is considered to be linked to the concept of Tawhid (the Oneness of God), as are all other branches of

\footnotetext{
${ }^{27}$ For details: Alexei NESTERUK, "Christianity, Orthodox, issues in Science and Religion", in Encyclopedia of Science and Religion, J. Wentzel Vrede VAN HuYSSTEEN, ed., pp. 130-131; Fr. Alexandru-Corneliu ARION, Encounters with Reality. Landmarks for contemporary dialogue between theology and culture, pp. 28-95.

${ }^{28}$ In the Qur'an, the word Muslim refers not only to humans but also to other creatures and the inanimate world. Cf. Abd Al-Rahman AzZAM, The Eternal Message of Muhammad, Cambridge, UK: Islamic Texts Society, 1993, p. 42.

${ }^{29}$ Bruno GuIDERDONI, "Islam, contemporary issues in Science and Religion", in Encyclopedia of Science and Religion, p. 465.

30 Alparslan ACIKGENC, Islamic Science: Towards a Definition, Kuala Lumpur, Malaysia: International Institute of Islamic Thought and Civilization, 1996; Also, Alexandru-Corneliu ARION, „Rolul Islamului $\hat{\imath}$ cultura Europei“ (“The role of Islam in European culture”), in „Annals“ of „Valahia“University, Târgovişte, Faculty of Theology, 2004, pp. 238-252.
} 
knowledge. ${ }^{31}$ In Islam, nature is not seen as a separate entity, but rather as an integral part of Islam's holistic outlook on God, humanity, and the world. The Islamic view of science and nature is continuous with that of religion and God. This link implies a sacred aspect to the pursuit of scientific knowledge by Muslims, as nature itself is viewed in the Qur'an as a compilation of signs pointing to the Divine. ${ }^{32}$

Ibn al-Haytham $(\dagger 1040)^{33}$, an Arab Muslim, was an early proponent of the concept that a hypothesis must be proved by experiments based on confirmable procedures or mathematical evidence - hence understanding the scientific method 200 years before Renaissance scientists. Ibn al-Haytham described his theology:

"I constantly sought knowledge and truth, and it became my belief that for gaining access to the effulgence and closeness to God, there is no better way than that of searching for truth and knowledge". ${ }^{34}$

With the decline of Islamic Civilizations in the late Middle Ages and the rise of Europe, the Islamic scientific tradition shifted into a new period. Institutions that had existed for centuries in the Muslim world looked to the new scientific institutions of European powers. This changed the practice of science in the Muslim world, as Islamic scientists had to confront the western approach to scientific learning, which was based on a different philosophy of nature. ${ }^{35}$ From the time of this initial upheaval of the Islamic scientific tradition to the present day, Muslim scientists and scholars have developed a spectrum of viewpoints on the place of scientific learning within the context of Islam, none of which are universally accepted or practiced. However, most maintain the view that the acquisition of knowledge and scientific pursuit in general is not in disaccord with Islamic thought and religious belief. $^{36}$

In addition, the Islamic metaphysics underlying epistemology and ethics is deeply marked by the dialectic of the visible and of the invisible. Phenomena are the signs of divine action in the cosmos. In fact, God is present in the world, the creation of which God ceaselessly "renews" at every moment (tajdìd al-khalq). The articulation of this form of "opportunism" with causality - and modern science's determinism and indeterminism - remains to be elaborated. ${ }^{37}$

Finally, one has to provide content to the term Islamic science. The issue is simultaneously one of ethics (personal and collective), of epistemology, and of the metaphysical Weltanschauung it presupposes. When passing from theory to practice, each current of thought must face specific problems resulting not only from its specific position but also from the Muslim world's economic and social difficulties. What remains to be established is the degree to which the most ambitious project - that of Islamic science as Sacred Science - can amount to more than a nostalgic glance at the past and move on to the stage of its actual implementation by a spiritual and intellectual elite. The future of the

\footnotetext{
${ }^{31}$ Muzaffar IQBAL, Science \& Islam, Greenwood Press, 2007, pp. 67-68.

32 Toshihiko IzUTSU, God and Man in the Koran, Weltansckauung, Tokyo, 1964, p. 97. It was with this understanding that science was studied and understood in Islamic civilizations, specifically during the eighth to sixteenth centuries, prior to the colonization of the Muslim world.

${ }^{33} \mathrm{He}$ is one of the principal Arab mathematicians and, without any doubt, the best physicist.

${ }^{34}$ C. Plott, Global History of Philosophy: The Period of Scholasticism, Motilal Banarsidass, New Delhi, 2000, p. 465.

${ }_{35}^{35}$ Muzaffar IQBAL, Science \& Islam, p. 79.

36 Seyyid Hossein NASR, "Islam and Modern Science" (A Lecture). URL= http://www.muslimphilosophy.com/ip/nasr1.htm

${ }^{37}$ Isma'il Raji Al-FARUQI, ed., Islamization of Knowledge: General Principles and Work Plan, Washington, D.C.: International Institute of Islamic Thought, 1982.
} 
Islamic civilization's contribution to the development of universal knowledge is tied to the answer that will be given to that question. ${ }^{38}$

\section{RELIGION AND SCIENCE IN HINDUISM}

Modern science was brought to India during the 1800 s by the British as a part of the colonization process. The goal of science in the colony was not the advancement of science but rather the exploration of natural resources, flora, and fauna to feed the needs and demands of Britain and its ongoing industrial revolution. ${ }^{39}$

Traditionally, Hindu thinkers approach the still unresolved mystery of the universe by looking back to Brahman (the Divine) as somehow associated with the creation or production of the universe. Scientific theory has speculated that the universe may arise from a quantum vacuum state, which is a peculiar mixture of emptiness and activity. Ancient sages had similar thoughts. The Sanskrit concept of zero, when applied to Brahman, is identified with both fullness and emptiness. Zero also makes possible advances in mathematics and modern digital technology. The universe is ontologically characterized by the term Brahman from the root brh "to expand." The risis (old sages) thought of the universe as an "expanding Brahman," which is consistent with contemporary cosmological thinking. ${ }^{40}$

Traditional Indian thought is characterized by a holistic vision. Instead of breaking experience and reality up into isolated fragments, the Indian thinkers looked at the whole and reconciled tensions and seeming contradictions within overarching categories. Thus the poets of the Rigveda speak of vishva-jyoti, cosmic light as the principle and source of everything, and of $r t a$, the universal cosmic order connecting and directing all particular phenomena and events. The Upanishads organize the world by relating everything to the pañcabhutas (five elements: earth, water, light, wind, ether) and identify in Brahman an allembracing reality-principle. The name of the major deity of later Hinduism is Vishnu, the "all-pervading," whose body is the universe. Nature (prakrti) was never seen as mere object, but always as productive agent. Religion was a natural part of the universally accepted order of things. ${ }^{41}$

But what is of much interest for our paper is that research in the history of Indian science is still in an early stage and much work remains to be done. New material is regularly published in the well-established Indian Journal for the History of Science, Vedic Science, and other periodicals. Thus, Indian mathematics developed out of the requirements for the Vedic yajña. The Yajurveda knows terms for numbers up to $10^{12}$ (by comparison the highest number named by the Greeks was $10^{4}$ ). Later on the Indians coined terms for

\footnotetext{
38 Nasim BUTT, Science and Muslim Societies, London: Grey Seal, 1991, p. 208; Leif STENBERG, The Islamization of Science: Four Muslim Positions Developing an Islamic Modernity. Lund, Sweden: Lunds Universitet, 1996.

${ }^{39}$ In the colonial context of India there was also discrimination against deserving Indian scientists who were relegated to positions below their entitlement and paid half the salary of their British counterparts. Cf. William HALBFASS, India and Europe: An Essay in Understanding, Albany: State University of New York Press, 1988.

${ }^{40}$ The current idea of a Big Bang in which very dense matter explodes into an expanding universe is seen to be prefigured by the Upanishadic notion bindu - a dimensionless point that is a unity of both static and dynamic forces, the dynamic expressing itself as the universe of multiplicity while essentially remaining a unity or order (rta). Harold COWARD, "Hinduism, contemporary issues in Science and Religion", in Encyclopedia of Science and Religion, p. 402.

${ }^{41}$ D.M. Bose; S.N. SEN and B.V. SubbarayapPA, eds., A Concise History of Science in India, New Delhi, India: Indian National Science Academy, 1984, p. 235.
} 
numbers up to $10^{24}$ and $10^{53}$. Algebra, in spite of its Arabic name, is an Indian invention, and so are the zero and the decimal system, including the "Arabic" numerals. The names of some great Indian mathematicians and some particulars of their accomplishments are known. ${ }^{42}$

Vaisheshika, one of the six orthodox darshanas, offers a theory of atomism more ancient than that of the Greek philosopher Democritus, and a detailed analysis of visheshas, qualities and differences, after which the system is named. The Vaisheshika-sutra describes the formation of physical bodies from atoms through dyads and triads in a strict cause-effect series. The positioning of the atoms determines the qualities of a body. Vaisheshika also developed the notion of impetus, a concept that appeared in Western science only in the fourteenth century. ${ }^{43}$

India's spiritual fame in the West is of long standing. During the fourth century b.Ch. Alexander the Great, intrigued by the proverbial wisdom of the brahmins, sought out the company of what the Greeks called gymnosophists on his Indian expedition (eventually replacing his mentor Aristotle by Kálanos, an Indian sage). Six centuries later, the philosopher Plotinus joined the expedition of Emperor Gordian in order to meet the famed Indian sages. ${ }^{44}$

By the late twenty-first century, there are thousands of Indian scientists with a Hindu background. Most do not see a conflict between their religion and their science, but some do notice a difference in orientation. Some have been led to astounding discoveries through the application of ancient Hindu insights to new fields of enquiry. Thus the biologist Jagdish Chandra Bose (1860-1937) used the Upanishadic idea of the universal Atman to conduct groundbreaking research in plant physiology. The traditional Hindu holistic and personalistic orientation could serve as a necessary corrective to mainstream Western science ${ }^{45}$ with its Cartesian legacy of an impersonal mechanistic worldview and a purely pragmatic, analytic approach to nature.

\section{RELIGION AND SCIENCE IN BUDDHISM}

The fundamental Buddhist ideas of interdependence and impermanence are based on a rational apprehension of the world that can be likened to the modern scientific method. Because of this basic shared approach, Buddhism and science does not come into serious conflict. The primary concern of Buddhism is to relieve human spiritual suffering and not to clarify the laws of nature. Thus Buddhists have freely adopted the practical scientific technologies of each epoch and place. For Buddhists, scientific technology is neither good nor evil. However, Buddhism recognizes that a self-centered application of technology can harm the integrity of other life forms, and hard to these can in turn harm human beings.

\footnotetext{
${ }^{42}$ Thus Aryabhathiya I (fifth century C.E.), a link in a long chain of unknown earlier master mathematicians, knew the rules for extracting square and cubic roots. He determined the value of $\pi$ to four decimals and developed an alphabetical system for expressing numbers on the decimal place value model. For details, see: $\mathrm{T}$. Renga Rajan IYENGAR, Hinduism and Scientific Quest, Delhi, India: Motilal Banarsidass, 1997.

${ }^{43}$ However, the other darshana with which it has been paired, Nyaya, concerned with epistemology and logic, declares that such analysis is necessary for obtaining spiritual liberation. Cf. Brajendranath SEAL, The Positive Sciences of the Ancient Hindus, Delhi, India: Motilal Banarsidass, 1958.

${ }^{44}$ No less a modern Western scientist than Austrian physicist Erwin Schrödinger (1887-1961), who won the Nobel prize for physics in 1933, has paid tribute to that "other" science: "The subject of every science is always the spirit and there is only that much true science in every endeavor as it contains spirit". Erwin SCHRÖDINGER, My View of the World, London: Cambridge University Press, 1964, p. 495.

${ }^{45}$ Klaus K . KlOStERMAIER, "Hinduism, History of Science and Religion", in Encyclopedia of Science and Religion, p. 409.
} 
Buddhism emphasizes the holistic relationship of life and the harmonious coexistence of all beings and all things. ${ }^{46}$

Historically, Buddhists have placed highest value on a supermundane wisdom that is beyond secular attachments and have encouraged compassionate acts toward all living beings. For Buddhists, there was no need to take part in practices such as sacrificial rituals, divination, or astrology, which have been popular in the societies of the various countries Buddhism has entered. The natural sciences also never became a significant part of Buddhist practice, although Buddhists were eager to introduce into their practices the knowledge of medicine and pharmacology, as well as more practical scientific technologies from paper and ink making to metallurgy, sculpture, and architecture. Such practical knowledge provided them with advanced skills in building temples, carving and casting statues, and printing scriptures, all of which helped in spreading the teaching of Buddhism. As it was already pointed out, the concepts of zero and fractions were first discovered in India. And the very discovery of zero is considered to be related to the Buddhist concept of impermanence or anatman (no-self). ${ }^{47}$

Science focuses on the external world and seeks to analyze objectively the phenomena of the universe, including human beings, to clarify the principle behind each phenomenon and to apply its discoveries to society to bring comfort to human lives. On the other hand, Buddhist teaching focuses mainly on the inner self as it faces the reality of suffering. The Buddhist path aims at pinpointing and eradicating causes of suffering for the sake of the accomplishment of the totality of the individual human being and that being's peace of mind. Therefore, Buddhism, which focuses on the individual, did not develop a standpoint of observing the universe and natural phenomena objectively, and Buddhism did not attempt to formulate a mechanical model of the universe. ${ }^{48}$

Buddhism and science have increasingly been discussed as compatible, and Buddhism has entered into the science and religion dialogue. ${ }^{49}$ The case is made that the philosophic and psychological teachings within Buddhism share commonalities with modern scientific and philosophic thought. For example, Buddhism encourages the impartial investigation of Nature, the principal object of study being oneself. Some popular conceptions of Buddhism connect it to discourse regarding evolution, quantum theory, and cosmology, though most scientists see a separation between the religious and metaphysical statements of Buddhism and the methodology of science. ${ }^{50}$ In 1993 a model deduced from Jean Piaget's theory of cognitive development was published arguing that Buddhism is a fourth mode of thought beyond magic, science and religion. ${ }^{51}$

Buddhism has been described by some as rational and non-dogmatic, and there is evidence that this has been the case from the earliest period of its history, though some have suggested this aspect is given greater emphasis in modern times and is in part a

\footnotetext{
46 James A. Austin, Zen and the Brain: Toward an Understanding of Meditation and Consciousness, Cambridge, Mass.: MIT Press, 1998.

${ }^{47}$ Ronald Y. NAKASONE, Ethics of Enlightenment, Freemont, Calif.: Dharma Cloud Publishers, 1990, p. 158.

48 Jeremy W. HAYWARD and Francisco J. VARELA, eds., Gentle Bridges: Conversations with the Dalai Lama on the Science of Mind, Boston and London: Shambhala, 2001.

49 Amos Yong, Buddhism and Science: Breaking New Ground (review), Buddhist-Christian Studies, Volume 25, 2005, pp. 176-180.

50 Donald S. LOPEZ Jr., Buddhism and Science: A Guide for the Perplexed, University of Chicago Press, 2008, pp. $135-138$.

${ }^{51}$ Stanley Jeyaraja TAMBIAH, Magic, Science and Religion and the Scope of Rationality, Cambridge University Press, 1990.
} 
reinterpretation. ${ }^{52}$ Buddhist teacher S.N._Goenka describes Buddhadharma as a "pure science of mind and matter". He claims Buddhism uses precise, analytical philosophical and psychological terminology and reasoning. Goenka's presentation describes Buddhism not so much as belief in a body of unverifiable dogmas, but an active, impartial, objective investigation of things as they are. In science, a theory should be tested in several ways before it can be accepted by the scientific community. The Buddha also recommended, in the Kālāma Sūtra, that any teaching and insight given by any teacher should be tested by our own experience before it can be accepted as the truth.

Real insight or right view has the capacity to liberate, and to bring peace and happiness. The findings of science are also insight; they can be applied in technology, but can be applied also to our daily behaviour to improve the quality of our life and happiness. Buddhists and scientists can share with each other their ways of studying and practice and can profit from each other's insights and experience. ${ }^{53}$

The relationship between science and Buddhism is not contradictory, for each can mutually understand the knowledge and wisdom of the other and bring benefits to humans and the Earth. In order to nurture a productive relationship between Buddhism and science, three important attitudes should be maintained. First, there must be a transformation of viewpoint from self-centered interests to a universal vision. Second, people must respect the values of modern science, yet avoid reducing all existences to material or mathematical formulae. Third, people must stop simply discussing problems and start acting to protect living beings and the environment. ${ }^{54}$

In 1989, the 14th Dalai Lama of Tibet discussed his idea of the relationship between Buddhism and science when he accepted the Nobel Peace Prize. The problems people face today, such as violent conflicts, destruction of nature, poverty, hunger, and so on, are humancreated problems that can be resolved through human effort, understanding, and a sense of brotherhood and sisterhood. The Dalai Lama stated that people need to cultivate a universal responsibility for one another and the planet.

Buddhists and the spiritual leaders of many other religions support the Dalai Lama's vision. Buddhists believe that people should not negate science simply by pointing out the harms created by modern science. Rather, scientists and religious leaders need to make more efforts to cooperate and depend on each other to bring happiness to Earth and humans. ${ }^{55}$

\section{CONCLUSION}

The dialogue between science and religion is one of the most prominent and visible discourses of our time. The complex but enduring relationship between the sciences and diverse world religions has now transformed itself into what some are calling a new scholarly field of science and religion. This multifaceted conversation has developed into a

\footnotetext{
52 Judith SnOdgrass, Defining Modern Buddhism: Mr. and Mrs. Rhys Davids and the Pāli Text Society, Comparative Studies of South Asia, Africa and the Middle East, Volume 27, No. 1, 2007, pp. 186-202. Not all forms of Buddhism eschew dogmatism, remain neutral on the subject of the supernatural, or are open to scientific discoveries. Buddhism is a varied tradition and aspects include fundamentalism, devotional traditions, supplication to local spirits, and various superstitions.

53 Thich Nhat HANH, "Categories View/Events". Plumvillage.org. Archived from the original on June 4, 2012.

${ }^{54}$ Mary Evelyn TUCKER, and Duncan Ryuken WILLIAMS, eds., Buddhism and Ecology: The Interconnection of Dharma and Deeds, Boston: Harvard University Press, 1998, p. 245.

${ }_{55}$ Sidney PIBURN, ed., The Dalai Lama: A Policy of Kindness, New York: Snow Lion Publications, 1990; Jeremy W. HAYWARD and Francisco J. VARELA, eds., Gentle Bridges: Conversations with the Dalai Lama on the Science of Mind.
} 
sustained and dynamic discourse with direct implications for contemporary culture. This discourse affects all religions, in both their intellectual and social dimensions. It also analyzes, supports, and constrains the global impact of the sciences of our times.

In the last two-three decades public awareness of and interest in this complex and often contentious relationship between science and religion has reached an unprecedented level. Courses in science and religion are now taught worldwide at a great number of educational institutions. Centers for the study of science and religion are actively pursuing the challenges and complexities of this dialogue; local and international societies for science and religion have been, and are being, established. There is also an exploding number of publications, journals, newsletters, and papers. Most recently, the science and religion dialogue has established an impressive new presence on the Internet. ${ }^{56}$

Spectacular advances in the sciences no longer easily threaten religions around the world because the risks and devastating consequences of new technologies have problematized the formerly unquestioned ideal of scientific progress. Scientific advances still challenge basic religious convictions, however, and the intellectual representatives of the world's religious traditions grapple with scientific knowledge more effectively and pervasively than ever before, thanks to the science-religion dialogue. Today sciences as varied as the neurosciences, ecology, and biotechnology raise questions about human beings and the future of our planetary home, perhaps especially for those who possess a sense of the divine. Similarly, chaos theory, quantum mechanics, and the ever-deepening understanding of the role of chance in biological systems conspire to challenge the notions of ultimate reality and divine action espoused by religious traditions and sacred texts.

There are interesting, if controversial, reasons why Christian theologians have often taken the lead in discussing the relationship of the sciences to the religions. An unfortunate side effect of this leadership is that, at certain times and places in recent decades, the dialogue has seemed limited by the caricature that only Christianity fostered modern science. But this version of events is historically inaccurate and deeply misleading. The evidence is that all religious traditions and all forms of scientific work have something to gain as well as lose in the process of mutual interaction, and the historical record demonstrates profound and longstanding engagement between science and religion in all literate cultures. For instance, Niels Bohr, who developed the Bohr Model of the atom, said:

\footnotetext{
"For a parallel to the lesson of atomic theory...[we must turn] to those kinds of epistemological problems with which already thinkers like the Buddha and Lao Tzu have been confronted, when trying to harmonize our position as spectators and actors in the great drama of existence." ${ }^{, 57}$
}

Over and above, all the endeavors from both sides of human attempt to reaching at a better understanding of the Reality we live in, is so emphatically underscored by Romanianborn French physicist Basarab Nicolescu: "If Science and Religion accept to dialogue, then the Blind will see and the Deaf will hear." 58

\footnotetext{
${ }^{56}$ J. Wentzel Vrede VAn HuYssteEn, Preface at Encyclopedia of Science and Religion, p. VII.

${ }^{57}$ Niels BoHR, Atomic Physics and Human Knowledge, edited by John Wiley and Sons, 1958, p. 20.

58 "If Science and Religion accept to dialogue, then the Blind will see and the Deaf will hear", Basarab NICOLESCU interviewed by Petrișor Militaru and Marius Ene, in: Transdisciplinarity in Science and Religion, No. 6/2009, pp. 419-431; See, also: Fr. Alexandru-Corneliu ARION, "Encounters with Reality". Landmarks for contemporary dialogue between theology and culture, p. 451.
} 


\section{BIBLIOGRAPHY:}

[1] Acikgenc Alparslan, Islamic Science: Towards a Definition, Kuala Lumpur, Malaysia: International Institute of Islamic Thought and Civilization, 1996.

[2] Al-Faruqi Isma'il Raji, ed., Islamization of Knowledge: General Principles and Work Plan, Washington, D.C.: International Institute of Islamic Thought, 1982.

[3] Arion Alexandru-Corneliu, „Intâlniri cu Realitatea”. Repere pentru dialogul contemporan dintre teologie şi cultură ("Encounters with Reality". Landmarks for contemporary dialogue between theology and culture), Preface by Prof. Dr. Lucian Turcescu, Cetatea de Scaun, Târgovişte, 2017.

[4] —, „Rolul Islamului în cultura Europei“ (“The role of Islam in European culture”), in „Annals“ of „Valahia“University, Târgovişte, Faculty of Theology, 2004.

[5] - " "The origin of the world from science and religion perspectives", in: Icon of Faith, International Journal of Interdisciplinary Scientific Reasearch, Year 3, No. 6, June, 2017.

[6] Austin A. James, Zen and the Brain: Toward an Understanding of Meditation and Consciousness, Cambridge, Mass.: MIT Press, 1998.

[7] Azzam Abd Al-Rahman, The Eternal Message of Muhammad, Cambridge, UK: Islamic Texts Society, 1993.

[8] Barbour Ian, Religion in an Age of Science: The Gifford Lectures, 1989-1991, Vol. 1. San Francisco: Harper-Collins, 1990.

[9] Bohr Niels, Atomic Physics and Human Knowledge, edited by John Wiley and Sons, 1958.

[10] Bose D.M., Sen S.N. and Subbarayappa B.V., eds., A Concise History of Science in India, New Delhi, India: Indian National Science Academy, 1984.

[11] Boyle Robert, A Free Enquiry into the Vulgarly Received Notion of Nature (1686), ed.: Edward B. Davis and Michael Hunter, Cambridge, UK: Cambridge University Press, 1996.

[12] Brooke H. John, Science and Religion: Some Historical Perspectives. Cambridge, UK: Cambridge University Press, 1991.

[13] Butt Nasim, Science and Muslim Societies, London: Grey Seal, 1991.

[14] Cahan David, ed., From Natural Philosophy to the Sciences: Writing the History of NineteenthCentury Science, Chicago: University of Chicago Press, 2003.

[15] Clegg Brian, The First Scientist: A Life of Roger Bacon, Carroll and Graf Publishers, New York, 2003.

[16] Coyne V. George \& Heller Michael, A Comprehensible Universe. The Interplay of Science and Theology, Springer-Verlag, New York, 2008.

[17] Coward Harold, "Hinduism, contemporary issues in Science and Religion", in Encyclopedia of Science and Religion.

[18]Culp John, "Panentheism", The Stanford Encyclopedia of Philosophy (Summer 2017 Edition), Edward N. Zalta (ed.), URL = https://plato.stanford.edu/archives/sum2017/entries/panentheism/

[19] Davis B. Edward, "Christianity, History of Science and Religion", in Encyclopaedia of Science and Religion, J. Wentzel Vrede van Huyssteen, editor-in-chief, Thomson Gale, Macmillan Reference, USA, 2003.

[20] - "The Word and the Works: Concordism and American Evangelicals", in: Perspectives on an Evolving Creation, ed. Keith Miller. Grand Rapids, Mich.: Eerdmans, 2002.

[21] Frye Roland Mushat, "The Two Books of God", in Is God a Creationist?, Roland Mushat Frye, ed., New York: Scribner, 1983.

[22] Halbfass William, India and Europe: An Essay in Understanding, Albany: State University of New York Press, 1988.

[23] Haq Syed Nomanul,"Science in Islam", in: Oxford Dictionary of the Middle Ages, Oxford University Press, 2010.

[24] Harrison, Peter, The Territories of Science and Religion, University of Chicago Press, 2015.

[25] Hayward W. Jeremy and Varela J. Francisco, eds., Gentle Bridges: Conversations with the Dalai Lama on the Science of Mind, Boston and London: Shambhala, 2001.

[26] Iqbal Muzaffar, Science \& Islam, Greenwood Press, 2007.

[27] Iyengar T. Renga Rajan, Hinduism and Scientific Quest, Delhi, India: Motilal Banarsidass, 1997.

[28] Izutsu Toshihiko, God and Man in the Koran, Weltansckauung, Tokyo, 1964.

[29] Josephson Jason Ananda, The Invention of Religion in Japan, University of Chicago Press, 2012. 
[30] Lindberg C. David and Numbers L. Ronald, eds. God and Nature: Historical Essays on the Encounter between Christianity and Science, Berkeley: University of California Press, 1986.

[31]Lopez Jr., S. Donald, Buddhism and Science: A Guide for the Perplexed, University of Chicago Press, 2008.

[32] Nakasone Y. Ronald, Ethics of Enlightenment, Freemont, Calif.: Dharma Cloud Publishers, 1990.

[33] Nasr Seyyid Hossein, "Islam and Modern Science" (A Lecture). URL= http://www.muslimphilosophy.com/ip/nasr1.htm

[34] Nesteruk Alexei, "Christianity, Orthodox, issues in Science and Religion", in Encyclopedia of Science and Religion, J. Wentzel Vrede van Huyssteen.

[35] Peacocke Arthur, Theology for a Scientific Age: Being and Becoming-Natural, Divine, and Human, rev. edition, Minneapolis, Minn.: Fortress Press, 1993.

[36] Polkinghorne John, Belief in God in an Age of Science. New Haven, Conn., Yale University Press, 1998.

[37] Piburn Sidney, ed. The Dalai Lama: A Policy of Kindness, New York: Snow Lion Publications, 1990.

[38] Plott C., Global History of Philosophy: The Period of Scholasticism, Motilal Banarsidass, New Delhi, 2000.

[39]Relationship between religion and science. https://en.wikipedia.org/wiki/Relationship_between_religion_and_science\#cite_note-First_Scientist,_Clegg-4

[40] Russel Ferngren C.A., ed., Science \& Religion: A Historical Introduction, Johns Hopkins University Press, 2002.

[41] Schrödinger Erwin, My View of the World, London: Cambridge University Press, 1964.

[42] Seal Brajendranath, The Positive Sciences of the Ancient Hindus, Delhi, India: Motilal Banarsidass, 1958.

[43] Shapin Steven, The Scientific Revolution, University of Chicago Press, 1996.

[44] Snodgrass Judith, Defining Modern Buddhism: Mr. and Mrs. Rhys Davids and the Päli Text Society, Comparative Studies of South Asia, Africa and the Middle East, Volume 27, No. 1, 2007.

[45] Stenmark Mikael, How to Relate Science and Religion: A Multidimensional Model, Grand Rapids, Mich.: W.B. Eerdmans, 2004.

[46] Tambiah Stanley Jeyaraja, Magic, Science and Religion and the Scope of Rationality, Cambridge University Press, 1990.

[47] Tucker Mary Evelyn and Ryuken Williams Duncan, eds., Buddhism and Ecology: The Interconnection of Dharma and Deeds, Boston: Harvard University Press, 1998.

[48] Yong Amos, Buddhism and Science: Breaking New Ground (review), Buddhist-Christian Studies, Volume 25, 2005. 